\title{
Thrombocytosis Associated with Iron Deficiency Anemia; Is It A Masked Myeloproliferative Disorder?
}

\author{
Demir Eksikliği Anemisi İlişkili Trombositoz; \\ Maskeli Myeloproliferatif Hastalık Olabilir mi?
}

\author{
Senem Maral ${ }^{1}$ \\ 'Ankara Yıldırım Beyazıt University, Department of Hematology
}

\begin{abstract}
Objectives: Thrombocytosis is a frequent reason for hematological consultation. The etiology of thrombocytosis is classified as primary and secondary. While primary is result of clonal expansion due to myeloproliferative disorders (MPD), secondary thrombocytosis occurs due to a reactive state and regresses when that is resolved. Iron deficiency (IDA) is a frequent cause of reactive thrombocytosis in outpatients. The aim of this study was to investigate whether IDA and thrombocytosis mask a MPD in patients presenting with these complaints.

Materials and Methods: This prospective study included 5o patients who were admitted to our hematology clinic with thrombocytosis and IDA. Causes of reactive thrombocytosis such as infections, surgery, malignancies, inflammatory diseases, asplenia, and pregnancy were excluded. All patients received oral or intravenous(iv) iron replacement as anemia treatment. Anemia and thrombocyte (PLT) count were measured and recorded initially and at the end of first month. JAK2 V617F (JAK2) mutation was also checked due to MPD investigation.

Results: Hemoglobin $(\mathrm{Hb})$ and ferritin levels increased in the first month of treatment $(\mathrm{p}<0.001)$. Higher ferritin levels were recorded in patients treated intravenously. A significant decrease was detected in PLT count following iron replacement ( $\mathrm{p}<0.001$ ). In 2 female patients no significant decrease was achieved in PLT count and the level persisted despite increases in $\mathrm{Hb}$ and ferritin level. Positive (JAK2) mutation was detected and MPD was diagnosed in these 2 patients.

Conclusion: Clinicians should investigate patients presenting with IDA and thrombocytosis in terms of reactive causes such as infections, asplenia, malignancies, and inflammatory diseases. Furthermore, MPA should be kept in mind as well as other reactive causes if thrombocytosis persists despite successful IDA treatment.

Key words: Iron deficiency anemia (IDA), Thrombocytosis, JAK2 mutation
\end{abstract}

$\ddot{O} \mathbf{z}$

Amaç: Trombositoz hematoloji bölümünde istenen konsültasyonların sık nedenleri arasındadır. Trombositoz etyolojisi primer ve sekonder olarak sinıflandırılır. Primer trombositoz myeloproliferatif hastalık nedeni ile klonal bir üretim sonucu iken, sekonder trombositoz altta yatan reaktif bir neden sonucunda gelişir ve neden ortadan kalktığı zaman düzelir. Demir eksikliği anemisi (DEA) reaktif trombositozun sık nedenidir. Bu çalışmada amaç DEA ilişkili trombositoz nedeni ile başvuran hastalarda maskelenmiş bir myeloprolif hastalığın varlığını araştırmaktır.

Materyal ve Metot: DEA ve trombositoz nedeni ile hematoloji polikliniğine başvuran 50 hasta çalışmaya dahil edilmiştir. Enfeksiyon, yakın zamanda geçirilmiş cerrahi, malignite, inflamatuvar hastalıklar, aspleni gibi diğer reaktif trombositoz nedenleri ve gebelik çalışma dıșı bırakılmıștır. Tüm hastalara DEA tedavisinde oral veya intravenöz yol ile demir replasmanı uygulanmıştır. Tedavi öncesinde ve 1 . ayında anemi ve trombosit düzeyleri kontrol edilmiștir. Ayrica hastalarda myeloproliferatif hastalık araștırmasına yönelik JAK2 V6ı17F (JAK2) mutasyonu taraması yapılmıștır.

Bulgular: Demir tedavisini takiben hemoglobin $(\mathrm{Hb})$ ve ferritin düzeylerinde tedavini 1. ayında anlamlı yükselme izlenmiștir ( $\mathrm{p}<\mathrm{o}, \mathrm{ool}$ ). İntravenöz yol ile tedavi edilenlerde daha yüksek ferritin düzeyine ulaşılmıştır. Kontrollerde hastaların trombosit sayısında belirgin düşüş görülmüştür ( $\mathrm{p}<0,001)$. İki kadın hastada $\mathrm{Hb}$ ve ferritin değerleri yükselmesine rağmen, trombosit sayısında azalma izlenmemiștir. Bu iki hastada JAK mutasyon pozitifliği tespit edilerek, kronik myeloproliferatif hastalık tanısı konmuștur.

Sonuç: Klinisyenler trombositoz durumlarında reaktif nedenler arasında DEA yanı sıra eșlik eden enfeksiyonlar, aspleni, malignite ve inflamatuar hastalıklar da araștırmalıdır. DEA bașarı ile tedavi edilmesine rağmen trombositoz durumlarında altta yatan KMPH ayırıcı tanıda düşünülmelidir.

Anahtar kelimeler: Demir eksikliği anemisi (DEA), Trombositoz, JAK mutasyonu 
Yazışma Adresi / Correspondence:

Dr. Senem Maral

e-mail: senemmaral@gmail.com

Date of submission: 17.02.2019

Date of admission: 28.05 .2019

\section{Introduction}

Thrombocytosis is mainly classified as primary and secondary. Primary thrombocytosis is a clonal production of bone marrow that is observed in chronic MPD. Secondary thrombocytosis is a result of a reactive cause such as infections, surgery, malignancies, inflammatory diseases, trauma, asplenia, and iron deficiency anemia (IDA).$^{1-6}$

Iron deficiency is the most common etiology of anemia, accounting for $50 \%-60 \%$ of all anemia cases ${ }^{7}$ and thrombocytosis is reported in up to one third of patients with IDA. ${ }^{4}$

Although the mechanisms of IDA-associated thrombocytosis are not well understood, it may be the result of relationships between thrombopoietin levels, erythropoietin, ferritin, interleukin 6 and interleukin 11 and the thrombocyte count. Furthermore, thrombocyte count usually returns to normal limits after iron supplementation unless there is concomitant clonal bone marrow production. The aim of this study was to investigate whether IDA and thrombocytosis mask a MPD in patients presenting with these complaints.

\section{Material and Methods}

\section{Patients and Method}

The study included patients admitted to the Hematology Clinic because of anemia and coexistent thrombocytosis. Normal thrombocyte count was considered to be $150-400$ $10^{3} / \mathrm{mL}$. Anemia was defined as $\mathrm{Hb}<12.0 \mathrm{~g} / \mathrm{dl}$ for females and $\mathrm{Hb}<13 \mathrm{~g} / \mathrm{dl}$ for males. In this prospective study, patients were investigated in terms of the etiological causes of thrombocytosis and for the presence of JAK2 mutation in Ataturk Research and Traing Hospital Department of Hematology between 2015 and 2016. All patients were evaluated for comorbidities, medication, medical history for venous thromboembolic events, thrombocytosis, and infective causes such as urinary, respiratory, gastrointestinal and dermatological infections. Initially, white blood count (WBC), neutrophil count, and erythrocyte sedimentation rate (ESR) were evaluated. Patients who presented with signs of infection or parameters attributed to an infective process, folate or vitamin B12 deficiency, hemolysis, acute hemorrage, chronic inflammatory process, or pregnancy were excluded. JAK2 mutation was examined with PCR from peripheral venous blood samples. Iron replacement was given orally (ferrous sulfate $80-160 \mathrm{mg} /$ day) or intravenously (iron sucrose $500-1000 \mathrm{mg}$ ) as treatment for IDA. The response to treatment was evaluated at the end of the first month of treatment according to initial $\mathrm{Hb}$, mean corpuscular volume (MCV), WBC, neutrophil, and PLT counts, and ferritin and ESR levels.

\section{Ethical approval}

Written informed consent was obtained from patients. Approval for the study was granted by the Ethics Committee of Ankara Yıldırım Beyazıt University Ataturk 
Research and Training Hospital. All procedures were conducted in accordance with the principles of the Helsinki Declaration.

\section{Statistical analysis}

Statistical analyses were made using SPSS version 24.0 software (Chicago, IL, USA). Kolmogorov Smirnov test was used to determine the normality of the variables. The parametric variables were given as mean \pm standard deviation and nonparametric variables as median and IQR. Categorical variables were given as percentage (\%). The Wilcoxon test was used for comparing nonparametric variables; Paired sample-t test was used to compare the parametric variables. All statistical tests were two-sided, and a value of $\mathrm{p} \leq 0.05$ was considered statistically significant.

\section{Results}

The study included a total of 50 patients, comprising 47 (94\%) females and three (6\%) males with a mean age of $43.32 \pm 13.19$ years (range: 21-75 years). The patient characteristics are shown in Table 1.

Table 1. Characteristics of patients included study

\begin{tabular}{|l|c|}
\hline Patients (n: $\mathbf{5 0})$ & $\mathbf{n}(\mathbf{\%})$ \\
\hline Gender & $3(6)$ \\
Male & $47(94)$ \\
Female & $\mathbf{2}(4)$ \\
\hline Jak Mutation (+) & $\mathbf{2}(4)$ \\
\hline Thromboembolic events in history & \\
\hline
\end{tabular}

Iron therapy was administered intravenously (IV) to seven patients (14\%) due to a history of intolerance to oral iron medication. The comparison of all laboratory parameters pre- and post-treatment are shown in Table 2.

Table 2. Pre and post-treatment evaluation.

\begin{tabular}{|l|c|c|c|}
\hline Parameters & Pretreatment (n:50) & Posttreatment(n:50) & $\boldsymbol{p}$ \\
\hline WBC $\times 10^{3} / \mu \mathrm{L}$ & $9.42 \pm 2.38$ & $8.99 \pm 2.39$ & 0.173 \\
\hline Neutrophile $\mathrm{x10} 3 / \mu \mathrm{L}$ & $5.88 \pm 2.14$ & $5.60 \pm 1.87$ & 0.189 \\
\hline Hemoglobin $(\mathrm{g} / \mathrm{dL})$ & $9.88 \pm 1.48$ & $12.57 \pm 1.47$ & $<0.001$ \\
\hline $\begin{array}{l}\text { Platelet x109/ } \mu \mathrm{L}, \text { median } \\
(\mathrm{IQR})\end{array}$ & $565(512-621)$ & $424(318-474)$ & $<0.001$ \\
\hline MCV $(\mathrm{fL})$ & $71.04 \pm 8.38$ & $80.22 \pm 8.21$ & $<0.001$ \\
\hline $\begin{array}{l}\text { Ferritin, median}(\mu \mathrm{g} / \mathrm{L}) \\
(\mathrm{IQR})\end{array}$ & $6(4-9)$ & $29(19-44)$ & $<0.001$ \\
\hline ESR & $11.62 \pm 4.93$ & $10.68 \pm 5.35$ & 0.299 \\
\hline
\end{tabular}

MCV: Mean Corpusclar Volume, ESR: Erythtrocyte Sedimentation Rate

Pre-treatment mean $\mathrm{Hb}$ and MCV of the patients were recorded as $9.88 \pm 1.48 \mathrm{~g} / \mathrm{dL}$ and $71 \mathrm{fL}$, respectively, compatible with IDA. Following iron replacement therapy, the mean 
$\mathrm{Hb}$ and MCV counts increased to $12.57 \pm 1.47 \mathrm{~g} / \mathrm{dL}$ and $8 \mathrm{o} \pm 8.10 \mathrm{fL}$, respectively ( $\mathrm{p}<0.001$ ). Median ferritin levels increased to $29 \mu \mathrm{g} / \mathrm{L}$ (IQR:19-44) from $6 \mu \mathrm{g} / \mathrm{L}$ (IQR:4-9) with iron replacement treatment $(\mathrm{p}<0.001)$.

All patients were evalauted for infective causes and chronic inflamatory processes before inclusion in the study. Pretreatment mean WBC and neutrophile counts were 9.42 $\pm 2.38 \times 10^{9} / \mathrm{L}$ and $5.88 \pm 2.14 \times 10^{9} / \mathrm{L}$ respectively. After treatment mean $\mathrm{WBC}$ and neutrophile counts were counted $8.99 \pm 2.39 \times 10^{9} / \mathrm{L}$ and $5.60 \pm 1.87 \times 10^{9} / \mathrm{L}$ (p:0.173 and p<0.0o1 resp.). Mean ESR, as an indicator of infection, was examined $11.62 \pm 4.92$ initially. With the treatment ESR was recorded 10.68 55.34 (p:0.299).

The median thrombocyte count was $565 \times 10^{9} / \mathrm{L}$ (IQR:512-621) before iron treatment and this decreased to $424 \times 10^{9} / \mathrm{L}$ (IQR:318-474) post-treatment $(\mathrm{p}<0.001)$. High thrombocyte counts persisted in two patients despite improvements in anemia and ferritin level after treatment. JAK2 mutation positivity was detected in these two patients $(4 \%)$. Bone biopsy was performed in three patients for definitive diagnosis. In the two patients with positive JAK2 mutation, diagnosis of myeloproliferative disorder (MPD) was confirmed by bone marrow biopsy. The third patient applied with bone biopsy was negative for JAK2 mutation but was evaluated as highly suspicious for MPD.

Venous thromboembolic events (pulmonary) were detected in the medical history of two patients independently of thrombocytosis and JAK mutation.

\section{Discussion}

Reactive thrombocytosis generally recovers when the cause such as infections, iron deficiency, malignancy, acute hemorrhage, inflammatory conditions is resolved. Alterations in thrombopoietin levels and proinflammatory cytokines play a role in reactive thrombocytosis pathophysiology. Iron deficiency is a common etiology of reactive thrombocytosis seen in out-patients. It is associated with increased proliferation of progenitor cells that are common to both thrombocytes and red blood cells.

IDA is the most frequent cause of anemia worldwide and is more prevalent in developing countries. Females are affected several-fold more than males ${ }^{8}$ especially women of reproductive age.- 9 The incidence of IDA is associated with social factors such as living in low- and middle-income countries. Saydam et al reported the prevalence of anemia in Turkish women as $27.8 \%$, of which $56 \%$ have IDA. ${ }^{10}$ In the current study, $94 \%$ of the patients were females of child-bearing age, with a mean age of 42.50 years.

All the patients in this study were treated with oral or IV iron replacement. Hb and ferritin levels increased in the first month of treatment ( $\mathrm{p}<0.001)$. Higher ferritin levels were recorded in patients treated intravenously. A significant decrease was detected in thrombocyte count following iron replacement $(\mathrm{p}<0.001)$. However, in two female patients no significant decrease was achieved and low levels persisted despite increases in $\mathrm{Hb}$ and ferritin levels. JAK2 mutation positivity was detected and MPD was diagnosed in these two patients.

In literature, JAK2 mutation frequency has been reported as $<1 \%$ in the normal population, and as $>50 \%$ in patients with myeloproliferative disorders- ${ }^{11-12}$ In the current study, the JAK 2 mutation frequency was determined to be $4 \%$. However, the 
cohort of this study was small and therefore there is a need for further studies with larger samples to provide more reliable results.

A positive correlation has been determined between thrombocyte count and elevated infection parameters such as C-reactive protein and ESR. ${ }^{13-14}$

In the current study, initially investigations were made in respect of infections and inflammatory conditions as the reason for thrombocytosis. No statistically significant difference was determined between the pre- and post-treatment median WBC and neutrophil counts, and ESR levels.

The relationship between reactive thrombocytosis and thromboembolism remains uncertain. In this study, a history of thromboembolic event was recorded in two patients independently of the thrombocyte count. However, etiological investigation of thromboembolism was not applied and no medication history was recorded. Patients were not prescribed anticoagulant or anti-aggreagant medications for thrombocytosis except for the diagnosis of MPD. None of the patients experienced any thromboembolic event during the period of thrombocytosis. There are few cases in literature of venous thrombosis due to reactive thrombosis..$^{16}$ In the absence of additional risk factors for thrombosis, no treatment for thromboembolic events is recommended. ${ }^{17-18}$

This study had some limitations due to lack of laboratory facilities. In addition to JAK2 mutation, exon 12, calreticulin and MLP mutation should be evaluated for MPD investigation. There is a need for larger cohort studies including these tests.

In conclusion, IDA is a cause of reactive thrombocytosis which is resolved with anemia treatment. In cases where thrombocytosis persists despite successful IDA treatment, MPD should be investigated in addition to other reactive causes.

\section{References}

1. Kasper CK, Whissell YE, Wallerstein RO. Clinical aspects of iron deficiency. JAMA 1965;191:35963.

2. Schloesser LL, Kipp MA, Wenzel FJ. Thrombocytosis in iron deficiency anemia. J Lab Clin Med 1965;66:107-14.

3. Griesshammer M, Bangerter M, Sauer T, Wennauer R, Bergmann L, Heimpel H. Aetiology and clinical significance of thrombocytosis: Analysis of 732 patients with an elevated thrombocyte count. J Intern Med 1999;245:295-300.

4. Kadikoylu G, Yavasoglu I, Bolaman Z, Senturk T. Thrombocyte parameters in women with iron deficiency anemia. J Natl Med Assoc 2006;98:398-402.

5. Dan K. Thrombocytosis in iron deficiency anemia. Intern Med 2005;44:1025-26.

6. Aydogan T, Kanbay M, Alici O, Kosar A. Incidence and etiology of thrombocytosis in an adult Turkish population. Thrombocytes 2006;17:328-31.

7. McLean E, Cogswell M, Egli I, Wojdyla D, de Benoist B. Worldwide prevalence of anaemia, WHO vitamin and mineral nutrition information system, 1993-2005. Public Health Nutr: 2009;12:444-54.

8. Kassebaum NJ, Jasrasaria R, Naghavi M. A systematic analysis of global anemia burden from 1990 to 2010. Blood. 2014;123:615.

9. Estadella J, Villamarín L, Feliu A, Perelló J ,Calaf J.Characterization of the population with severe iron deficiency anemia at risk of requiring intravenous iron supplementation. European Journal of Obstetrics \& Gynecology and Reproductive Biology, 2018:224;41-4.

10. Saydam BK, Genc RE, Sarac F, Turfan EC. Prevalence of anemia and related factors among women in Turkey. Pak J Med Sci= 2017; 33: 433-38.

11. Xu X, Zhang Q, Luo J, Xing S, Li Q, Krantz SB. JAK2 (V617F): Prevalence in a large Chinese hospital population. Blood 2007; 109: 339-42. 
12. Tevet M, Ionescu R, Dragan C, Lupu AR. Influence of the JAK2 V617F mutationand inherited thrombophilia on the thrombotic risk among patients with myeloproliferative disorders. Maedica (Buchar) 2015; 10: 27-32.

13. Tefferi A, Ho TC, Ahmann GJ Katzmann JA, Greipp PR. Plasma interleukin-6 and C-reactive protein levels in reactive versus clonal thrombocytosis. Am J Med 1994:97;374-78.

14. Alexandrakis MG, Passam FH, Moschandrea IA, Christophoridou AV, Pappa CA, Coulocheri SA et al. Levels of serum cytokines and acute phase proteins in patients with essential and cancerrelated thrombocytosis. Am J Clin 2003:26; 135-40.

15. Yoshida S, Kohro S, Yamakage M Nakayama M, Namiki A. A case of suspected pulmonary thrombosis in a patient with reactive thrombocytemia who underwent liver subsegmentectomy. Masui.2003;52:1320-22.

16. Mishra SB, Bhoyer J, Gurjar M, Muzaffar N, Verma A. Deep vein thrombosis of upper extremities due to reactive thrombocytosis in septic patients. Indian J Crit Care Med. 2014;18:540-42.

17. Evstatiev R. Iron deficiency, thrombocytosis and thromboembolism. Wien Med Wochenschr= 2016;166:437-46.

18. Hengeveld PJ, Hazenberg MD, Biezeveld MH, Raphael MF. Risk of thrombosis is a reactive thrombocytosis. Ned Tijdschr Geneeskd. 2018;162: 2697. 